\title{
Advanced melanoma in adults: Pembrolizumab as a treatment option
}

\author{
Participants: \\ Antonio Silvinato ${ }^{1}$ \\ Wanderley Marques Bernardo² \\ id Idevaldo Floriano ${ }^{1}$
}

Created on: November 6, 2019

1. Associacao Médica Brasileira, São Paulo, SP, Brasil 2. Coordenador do Programa Diretrizes da Associação Médica Brasileira, São Paulo, SP, Brasil

E-mail:wmbernardo@usp.br

The Guidelines Project, an initiative of the Brazilian Medical Association, aims to combine information from the medical field in order to standardize producers to assist the reasoning and decision-making of doctors.

The information provided through this project must be assessed and criticized by the physician responsible for the conduct that will be adopted, depending on the conditions and the clinical status of each patient.

PD-1 (programmed cell death protein 1) is a immunologic checkpoint that limits the activity of $\mathrm{T}$ cells (lymphocytes) in peripheral tissues. Pembrolizumab is a IgG4 monoclonal antibody, highly selective and humanized, which binds to the programmed cell death protein 1 receptor and blocks its interaction with the PD-L1 and PD-L2 ligands. A systematic review was performed using the PICO search system Adult patients with advanced melanoma (completely resectable or unresectable) without distant metastasis (patient) Treatment with pembrolizumab compared with another or no therapy (intervention) death (any cause); death or recurrence; and adverse events (outcome). The search process resulted in 323 papers, of which three were included. The details of the methodology and the results of this guideline are set out in Annex 1.

\section{INTRODUCTION}

PD-1 (programmed cell death protein 1) is a immunologic checkpoint that limits the activity of $\mathrm{T}$ cells (lymphocytes) in peripheral tissues. The PD-1 pathway is a immunological control checkpoint that can be coupled by tumor cells to inhibit immune surveillance of the active $\mathrm{T}$ cell.

Pembrolizumab is a IgG4 monoclonal antibody that is highly selective, humanized, and binds to the programmed cell death protein 1 receptor and blocks its interaction with the PD-L1 and PD-L2 ligands, which are expressed in antigen-presenting cells and may be expressed by tumors or other cells in the tumor microenvironment, assisting them in preventing of their detection and elimination by the immune system of the host.

The involvement of PD1 on the surface of lymphocytes by PD-L1 in melanoma cells provides inhibitory signals that negatively regulate the function of $\mathrm{T}$ cells.

The advent of monoclonal antibodies that target CTLA-4 (ipilimumab) or PD-1 (nivolumab and pembrolizumab) checkpoints increased the expectations for better outcomes in advanced melanoma. However, resistance remains an important issue. Genetic 
mutations and deregulation of the immune system may be a factor in some patients and have a significant impact on the effectiveness of therapies.

\section{RESULTS}

Our study population included 2,393 patients with advanced melanoma who underwent pembrolizumab therapy $(\mathrm{N}=971)$ compared to ipilimumab $(\mathrm{N}=278)$, chemotherapy $(\mathrm{N}=179)$, or a placebo $(\mathrm{N}=505)$ and followed-up to measure the outcomes of death and adverse events at 6 or 12 months (Table 1).

Regarding the bias risk of the three studies included, two of them were not double-blind ${ }^{(3,4)}$, and all had losses $>20 \%$, so the overall risk of the studies can be considered moderate (Table 2).

All studies assessed the outcome of death from any cause, and one of them assessed the composite outcome of death or recurrence (local, regional, or distant metastasis $^{(5)}$ (Table 3).

TABLE 1. CHARACTERISTICS OF THE STUDIES INCLUDED

\begin{tabular}{|c|c|c|c|c|c|}
\hline \multicolumn{6}{|c|}{ DESCRIPTIVE TABLE OF STUDY CHARACTERISTICS } \\
\hline STUDY & Population & Intervention & Comparison & $\begin{array}{l}\text { Out- } \\
\text { comes }\end{array}$ & $\begin{array}{l}\text { Time (medi- } \\
\text { an, months) }\end{array}$ \\
\hline $\begin{array}{l}\text { SCHACHTER, } \\
2017 \\
\text { KEYNOTE-006 }\end{array}$ & $\begin{array}{l}834 \text { patients > } 18 \text { years (62 years median) with: } \\
\text { melanoma confirmed histologically; unresectable; } \\
\text { stage III or IV; without prior therapy with ipilimumab } \\
\text { (previous treatment with one or two other therapies } \\
\text { was allowed); wild-type or mutant Braf; Ecog } 0 \text { to 1; } \\
\text { at least a measurable lesion per Recist version 1.1. } \\
\text { Exclusion criteria: previous therapy with CTLA, PD-1, } \\
\text { or PD-L1 inhibitors, ocular melanoma, cerebral me- } \\
\text { tastasis, and severe autoimmune disease requiring } \\
\text { corticosteroid therapy. }\end{array}$ & $\begin{array}{l}\text { Pembrolizumab } 10 \\
\mathrm{mg} / \mathrm{kg} \\
\text { 2/2 weeks or } \\
\text { 3/3 weeks (Q3W) }\end{array}$ & $\begin{array}{l}\text { Ipilimumab } 3 \\
\text { mg/kg } \\
\text { 3/3 weeks, } 4 \\
\text { cycles }\end{array}$ & $\begin{array}{l}\text { OS } \\
\text { SFP } \\
\text { Adverse } \\
\text { events }\end{array}$ & 22.9 \\
\hline $\begin{array}{l}\text { HAMID, } \\
2017 \\
\text { KEYNOTE-002 } \\
\text { Stage II }\end{array}$ & $\begin{array}{l}540 \text { patients (median age of } 62 \text { years) with progres- } \\
\text { sive unresectable melanoma in stage III-IV after } \\
\text { ipilimumab or therapy with MEK or Braf inhibitor (or } \\
\text { both), if positive mutant Braf } \mathbf{6 0 0} \text {; } \\
\text { Ecog status of O or } 1 \text {; at least one measurable lesion. } \\
\text { We excluded patients with active brain metastases } \\
\text { or carcinomatous meningitis, active autoimmune } \\
\text { disease, active infection requiring systemic therapy; } \\
\text { HIV infection, active virus of hepatitis B or C, history } \\
\text { of adverse events related to ipilimumab grade } 4 \text { or } 3 \text {, } \\
\text { or previous treatment with any other anti-PD-1 or } \\
\text { anti-PD-L1 therapy. }\end{array}$ & $\begin{array}{l}\text { Pembrolizumab } \\
2 \text { mg/kg, IV Q3W } \\
\text { or } \\
10 \text { mg/kg Q3W }\end{array}$ & $\begin{array}{l}\text { Chemotherapy } \\
\text { chosen by the } \\
\text { investigator } \\
\text { (paclitaxel plus } \\
\text { carboplatin, } \\
\text { paclitaxel, } \\
\text { carboplatin, } \\
\text { dacarbazine, or } \\
\text { oral temozolo- } \\
\text { mide) }\end{array}$ & $\begin{array}{l}\text { OS } \\
\text { Adverse } \\
\text { events }\end{array}$ & 28 \\
\hline $\begin{array}{l}\text { EGGER } \\
\text { MONT, } \\
2018 \\
\text { KEYNOTE-O54 }\end{array}$ & $\begin{array}{l}\text { 1,019 patients >18 years ( } 54 \text { years median) with } \\
\text { metastatic cutaneous melanoma for regional lymph } \\
\text { node, stage IIIA, IIIB, or IIIC, with complete resection } \\
\text { and without distant metastasis. } \\
\text { Complete regional lymphadenectomy was performed } \\
\leq 13 \text { weeks prior to the initiation of treatment. } \\
\text { Exclusion criteria: Ecog >1(0-5); autoimmune dis- } \\
\text { eases; uncontrolled infections; use of corticosteroids, } \\
\text { and previous therapy for melanoma. } \\
84 \% \text { had a positive expression of PD-L1 (>1\% of } \\
\text { expression). }\end{array}$ & $\begin{array}{l}\text { Pembrolizumab } \\
200 \text { mg IV every } 3 \\
\text { weeks (Q3W), up } \\
\text { to } 18 \text { doses, or until } \\
\text { disease recurrence } \\
\text { or unacceptable } \\
\text { toxic effect }\end{array}$ & Placebo & $\begin{array}{l}\text { OS } \\
\text { SFP } \\
\text { Adverse } \\
\text { events } \\
\text { Quality of } \\
\text { life }\end{array}$ & 15.1 \\
\hline
\end{tabular}

Q3W = every 3 weeks; Ecog = Eastern Cooperative Oncology Group (minimum score of 0 and maximum of 5)

TABLE 2. DESCRIPTION OF THE BIASES OF THE STUDIES INCLUDED

\begin{tabular}{l|l|l|l|l|l|l|l|l}
\hline Study/Year & Random & $\begin{array}{l}\text { Blinded } \\
\text { allocation }\end{array}$ & $\begin{array}{l}\text { Double- } \\
\text { blind }\end{array}$ & Losses & $\begin{array}{l}\text { Prog. } \\
\text { Charac- } \\
\text { teristics }\end{array}$ & Outcome & $\begin{array}{l}\text { ITT } \\
\text { Analysis }\end{array}$ & $\begin{array}{l}\text { Sample } \\
\text { size cal- } \\
\text { culation }\end{array}$ \\
\hline Schachter, 2017 & & & & & & & \\
\hline Hamid, 2017 & & & & & & & \\
\hline Egger Mont, 2018 & & & & & & & \\
\hline
\end{tabular}

ITT = intention-to-treat analysis. (blue) Low risk of bias (orange) Presence of bias (yellow) Unclear risk of bias 
TABLE 3. STUDY RESULTS FOR THE OUTCOME OF DEATH

\begin{tabular}{|c|c|c|c|c|}
\hline Study & $\begin{array}{l}\text { Pembro } \\
\text { patients/ } \\
\text { events }\end{array}$ & $\begin{array}{l}\text { Ipilimumab } \\
\text { patients/ } \\
\text { events }\end{array}$ & $\begin{array}{l}\text { QT (paclitaxel plus carboplatin, paclitaxel, } \\
\text { carboplatin, dacarbazine, or oral temozolo- } \\
\text { mide) }\end{array}$ & Placebo \\
\hline $\begin{array}{l}\text { Schachter, 2017(3) } \\
\text { Keynote-006 }\end{array}$ & $\begin{array}{l}\text { IN } 12 \text { MONTHS } \\
277 / 93 \\
\text { Death outcome } \\
10 \text { mg/kg; Q3W }\end{array}$ & 278/133 & & \\
\hline $\begin{array}{l}\text { Hamid, } \\
2017(4) \\
\text { Keynote-002 }\end{array}$ & $\begin{array}{l}\text { IN } 12 \text { MONTHS } \\
180 / 85 \\
\text { Death outcome } \\
2 \text { mg/kg; Q3W }\end{array}$ & & $179 / 99$ & \\
\hline $\begin{array}{l}\text { Eggermont, } \\
\text { 2017(5) } \\
\text { Keynote } 054\end{array}$ & $\begin{array}{l}\text { IN } 6 \text { MONTHS } \\
514 / 101 \\
\text { Death or recurrence outcome } \\
200 \mathrm{mg} \text { Q3W }\end{array}$ & & & $505 / 142$ \\
\hline
\end{tabular}

Q3W = every 3 weeks

\section{Pembrolizumab vs. Ipilimumab (1-year follow-up)}

The study allows us to evaluate the outcome of death in up to 12 months, comparing pembrolizumab (10 $\mathrm{mg} / \mathrm{Kg}$, Q3W) with ipilimumab and shows a reduction of $14 \%$ (95\% CI, 22 to $6 \%$ ), favoring the use of pembrolizumab ( $\mathrm{p}=0.0005)$; it is necessary to treat (NNT) seven patients (95\% CI, 4 to 16$)$ to prevent one death in this period (Figure 2).

\begin{tabular}{|c|c|c|c|c|c|c|c|c|}
\hline Study or Subgroup & \multicolumn{2}{|c|}{ PEMBRO } & \multicolumn{2}{|c|}{ Ipilimumab } & Weight & $\begin{array}{l}\text { Risk Difference } \\
\text { M-H, Fixed, } 95 \% \mathrm{Cl}\end{array}$ & \multicolumn{2}{|c|}{$\begin{array}{c}\text { Risk Difference } \\
\text { M-H, Fixed, } 95 \% \mathrm{Cl}\end{array}$} \\
\hline Schachter J, 2017 & 93 & 277 & 133 & 278 & $100.0 \%$ & $-0.14[-0.22,-0.06]$ & - & \\
\hline Total $(95 \% \mathrm{Cl})$ & & 277 & & 278 & $100.0 \%$ & $-0.14[-0.22,-0.06]$ & & \\
\hline Total events & 93 & & 133 & & & & & \\
\hline $\begin{array}{l}\text { Heterogeneity: Not a } \\
\text { Test for overall effec }\end{array}$ & $\begin{array}{l}\text { olicable } \\
Z=3.46(\end{array}$ & $P=0.0$ & 005) & & & & $\begin{array}{cc}-0.2 & -0.1 \\
\text { Favours PEMBRO }\end{array}$ & 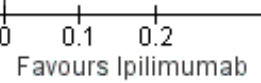 \\
\hline
\end{tabular}

FIGURE 2. COMPARISON CHART: 1. PEMBROLIZUMAB VERSUS IPILIMUMAB IN THE TREATMENT OF ADVANCED MELANOMA, OUTCOME: DEATH IN UP TO 12 MONTHS.

\section{Pembrolizumab vs. Chemotherapy (1-year follow-up)}

Only one study compared pembrolizumab (2 mg/kg, Q3W) versus chemotherapy, as chosen by the investigator (paclitaxel plus carboplatin and paclitaxel, carboplatin, dacarbazine, or oral temozolomide), and allows to evaluate the outcome of death within 12 months.

There was no difference between the two therapies in relation to the risk of within 12 months [Absolute Risk Reduction (ARR) $=-0.08$ (-0.18 to 0.02); $p=0.012$; the result is not significant] (Figure 3).

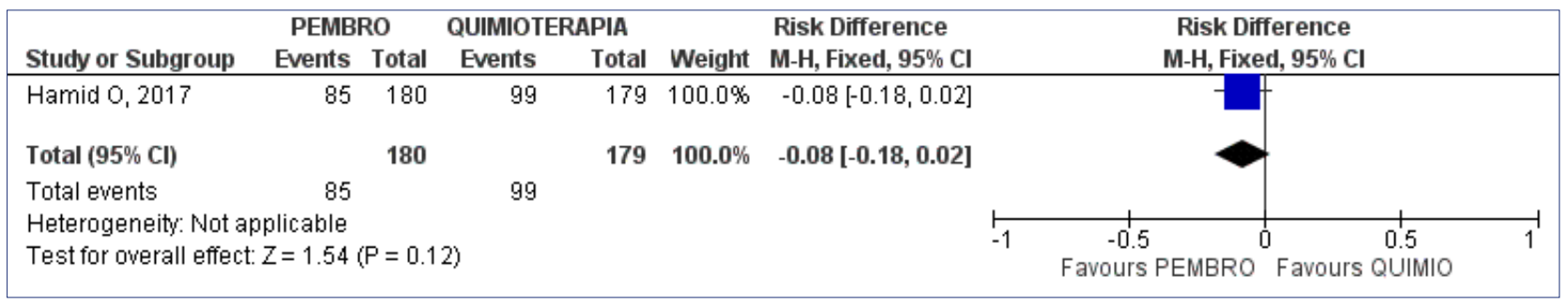

FIGURE 3. COMPARISON CHART: 2. PEMBROLIZUMAB VERSUS CHEMOTHERAPY IN THE TREATMENT OF ADVANCED MELANOMA, OUTCOME: DEATH IN UP TO 12 MONTHS. 


\section{Pembrolizumab vs. Placebo (6-month follow-up)}

The study allows us to calculate the risk of death or recurrence within six months, comparing pembrolizumab (200 mg, Q3W) versus a placebo. There was a reduction in the risk of death or recurrence by $8 \%$ (IC 95\%, $14 \%$ to $3 \%$ ) favorable to pembrolizumab ( $\mathrm{p}=0.001$ ); it is necessary to treat (NNT) 12 patients (95\%, CI 7 to 30 ) to avoid one recurrence or death in up to six months, Figure 4.

\begin{tabular}{|c|c|c|c|c|c|c|c|c|}
\hline \multirow{2}{*}{$\begin{array}{l}\text { Study or Subgroup } \\
\text { Eggermont AM, } 2018\end{array}$} & \multicolumn{2}{|c|}{ PEMBRO } & \multicolumn{2}{|c|}{ Placebo } & Weight & $\begin{array}{l}\text { Risk Difference } \\
\text { M-H, Fixed, 95\% Cl }\end{array}$ & \multicolumn{2}{|c|}{$\begin{array}{l}\text { Risk Difference } \\
\text { M-H, Fixed, } 95 \% \mathrm{Cl}\end{array}$} \\
\hline & 101 & 514 & 142 & 505 & $100.0 \%$ & $-0.08[-0.14,-0.03]$ & $7-$ & \\
\hline Total $(95 \% \mathrm{Cl})$ & & 514 & & 505 & $100.0 \%$ & $-0.08[-0.14,-0.03]$ & & \\
\hline Total events & 101 & & 142 & & & & & \\
\hline $\begin{array}{l}\text { Heterogeneity: Not ap } \\
\text { Test for overall effect: }\end{array}$ & $\begin{array}{l}\text { icable } \\
=3.18(\mathrm{P}\end{array}$ & $=0.00$ & & & & & $\begin{array}{lll}-0.2 & -0.1 & 0 \\
\text { Favours } & \text { PEMBRO }\end{array}$ & \begin{tabular}{|ccc}
0 & 0.1 & 0.2 \\
Favours PLACEBO
\end{tabular} \\
\hline
\end{tabular}

FIGURE 4. COMPARISON CHART: 3. PEMBROLIZUMAB VERSUS PLACEBO IN THE TREATMENT OF ADVANCED MELANOMA, OUTCOME: DEATH OR RECURRENCE IN UP TO 6 MONTHS.

\section{ADVERSE EVENTS}

All three comparisons of pembrolizumab ${ }^{(3-5)}$ evaluated adverse events grade $\geq 3$, regardless of the cause, in the population treated, Table 4. Pembrolizumab showed no difference in the number of adverse events grade $\geq 3$ in comparison with ipilimumab ( $\mathrm{ARR}=2.9$, CI 95\% -0.03 to 0.09; NNT=NS), however, it reduced the risk by $12.8 \%$ (95\% CI, $45 \%$ to $21 \%$ ) in comparison with chemotherapy (NNT=8, 95\% CI, 5 to 22). In comparison with the placebo, pembrolizumab increased the risk of adverse events grade $\geq 3$ by $13 \%$ ( $95 \% \mathrm{CI}, 18 \%$ to $7.8 \%$ ).

TABLE 4. ADVERSE EVENTS GRADE $\geq I I I$ - ALL CAUSES - IN THE POPULATION TREATED

\begin{tabular}{|c|c|c|c|c|c|c|}
\hline Study & $\begin{array}{l}\text { Pembro } \\
\text { patients/ } \\
\text { events }\end{array}$ & $\begin{array}{l}\text { Ipilimumab } \\
\text { patients/ } \\
\text { events }\end{array}$ & $\begin{array}{l}\text { QT (paclitaxel plus } \\
\text { carboplatin, paclitaxel, } \\
\text { carboplatin, dacarbazine, } \\
\text { or oral temozolomide) }\end{array}$ & Placebo & $\begin{array}{l}\text { ARR\% } \\
\text { or ARI\% } \\
(\mathrm{Cl} 95 \%)\end{array}$ & $\begin{array}{l}\text { NNT or NNH } \\
(\mathrm{Cl} 95 \%)\end{array}$ \\
\hline $\begin{array}{l}\text { Schachter, } 2017 \\
\text { Keynote-006 }\end{array}$ & $\begin{array}{l}277 / 46 \\
10 \text { mg/kg; Q3W }\end{array}$ & $256 / 50$ & & & $\begin{array}{l}A R R=2.9 \\
(-0.036 \text { to } 0.094)\end{array}$ & $N N T=N S$ \\
\hline $\begin{array}{l}\text { Hamid, } \\
2017 \\
\text { Keynote-002 }\end{array}$ & $\begin{array}{l}178 / 24 \\
2 \text { mg/kg; Q3W }\end{array}$ & & $171 / 45$ & & $\begin{array}{l}A R R=12,8 \\
(0.045 \text { to } 0.211)\end{array}$ & $\begin{array}{l}\text { NNT }=8 \\
(5 \text { to } 22)\end{array}$ \\
\hline $\begin{array}{l}\text { Eggermont, } \\
2018 \\
\text { Keynote-054 }\end{array}$ & $\begin{array}{l}\text { 509/161 } \\
200 \text { mg Q3W }\end{array}$ & & & $502 / 93$ & $\begin{array}{l}A R I=-13.1 \\
(-0.184 \text { to } \\
-0.078)\end{array}$ & $\begin{array}{l}\mathrm{NNH}=8 \\
(3 \text { to } 13)\end{array}$ \\
\hline
\end{tabular}

$\mathrm{ARR}=$ absolute risk reduction; $\mathrm{ARI}$ = absolute risk increase; $\mathrm{NNT}$ = number needed to treat; $\mathrm{NNH}=$ number need to harm; $\mathrm{Cl}=$ confidence interval

\section{SYNTHESIS OF THE RESULTS FOR THE OUTCOME OF DEATH}

\begin{tabular}{|c|c|c|c|c|}
\hline Outcome or subgroup & Studies & Participants & Statistical Method & Estimated effect \\
\hline 1. Death iN up to 12 months Pembro vs. Ipilimumab & $1^{3}$ & 555 & $\begin{array}{l}\text { Difference in risk }(\mathrm{M}-\mathrm{H} \text {, } \\
\text { Fixed, } 95 \% \mathrm{Cl})\end{array}$ & $\begin{array}{l}-0.14[-0.22 \\
-0.06]\end{array}$ \\
\hline 2. Death in up to 12 months Pembro vs. Chemo & $7^{4}$ & 359 & $\begin{array}{l}\text { Difference in risk }(\mathrm{M}-\mathrm{H} \text {, Fixed, } \\
95 \% \mathrm{Cl})\end{array}$ & $\begin{array}{l}-0.08[-0.18 \\
0.02]\end{array}$ \\
\hline 3. Death or recurrence in up to 6 months Pembro vs. Placebo & $7^{5}$ & 1,019 & $\begin{array}{l}\text { Difference in risk }(\mathrm{M}-\mathrm{H} \text {, Fixed, } \\
95 \% \mathrm{Cl})\end{array}$ & $\begin{array}{l}-0.08[-0.14 \\
-0.03]\end{array}$ \\
\hline
\end{tabular}




\section{QUALITY OF EVIDENCE FOR THE OUTCOME OF DEATH}

1. Pembrolizumab versus Ipilimumab

\begin{tabular}{|c|c|c|c|c|c|c|c|c|c|c|c|c|}
\hline \multicolumn{7}{|c|}{ Evaluation of certainty } & \multicolumn{2}{|c|}{ No of patients } & \multicolumn{2}{|l|}{ Effect } & \multirow[t]{2}{*}{ Certainty } & \multirow{2}{*}{$\begin{array}{l}\text { Impor- } \\
\text { tance }\end{array}$} \\
\hline $\begin{array}{l}\mathrm{N}^{0} \text { of } \\
\text { stud- } \\
\text { ies }\end{array}$ & $\begin{array}{l}\text { Design } \\
\text { of the } \\
\text { study }\end{array}$ & $\begin{array}{l}\text { Risk of } \\
\text { bias }\end{array}$ & $\begin{array}{l}\text { Incon- } \\
\text { sistency }\end{array}$ & $\begin{array}{l}\text { Indirect } \\
\text { evi- } \\
\text { dence }\end{array}$ & $\begin{array}{l}\text { Impre- } \\
\text { cision }\end{array}$ & $\begin{array}{l}\text { Other } \\
\text { consider- } \\
\text { ations }\end{array}$ & $\begin{array}{l}\text { Pem- } \\
\text { broli- } \\
\text { zumab }\end{array}$ & $\begin{array}{l}\text { Ipilim- } \\
\text { umab }\end{array}$ & $\begin{array}{l}\text { Relative } \\
(95 \% \mathrm{Cl})\end{array}$ & $\begin{array}{l}\text { Absolute } \\
(95 \% \mathrm{Cl})\end{array}$ & & \\
\hline \multicolumn{13}{|c|}{ Death in up to 12 months } \\
\hline 1 & $\mathrm{RCT}$ & severe $^{\mathbf{a}}$ & $\begin{array}{l}\text { not } \\
\text { severe }\end{array}$ & $\begin{array}{l}\text { not } \\
\text { severe }\end{array}$ & $\begin{array}{l}\text { not } \\
\text { severe }\end{array}$ & None & $\begin{array}{l}93 / 277 \\
(33.6 \%)\end{array}$ & $\begin{array}{l}133 / 278 \\
(47.8 \%)\end{array}$ & $\begin{array}{l}\text { RR } 0.70 \\
(0.57 \text { to } \\
0.86)\end{array}$ & $\begin{array}{l}\text { minus } 14 \\
\text { per } 100 \\
\text { (from mi- } \\
\text { nus } 21 \text { to } \\
\text { minus } 7 \text { ) }\end{array}$ & $\begin{array}{l}\oplus \oplus \oplus \bigcirc \\
\text { MODER- } \\
\text { ATE }\end{array}$ & $\begin{array}{l}\text { IM- } \\
\text { PORT- } \\
\text { ANT }\end{array}$ \\
\hline
\end{tabular}

RCT: Randomized clinical trial; Cl: Confidence interval; RR: Risk ratio

\section{Explanations}

a. A loss greater than $20 \%$

\section{Pembrolizumab versus Chemotherapy}

\begin{tabular}{|c|c|c|c|c|c|c|c|c|c|c|c|c|}
\hline \multicolumn{7}{|c|}{ Evaluation of certainty } & \multicolumn{2}{|c|}{ No of patients } & \multicolumn{2}{|l|}{ Effect } & \multirow{2}{*}{$\begin{array}{l}\text { Certain- } \\
\text { ty }\end{array}$} & \multirow{2}{*}{$\begin{array}{l}\text { Im- } \\
\text { por- } \\
\text { tance }\end{array}$} \\
\hline $\begin{array}{l}\mathrm{N}^{\circ} \text { of } \\
\text { studies }\end{array}$ & $\begin{array}{l}\text { Design } \\
\text { of the } \\
\text { study }\end{array}$ & $\begin{array}{l}\text { Risk of } \\
\text { bias }\end{array}$ & $\begin{array}{l}\text { Incon- } \\
\text { sistency }\end{array}$ & $\begin{array}{l}\text { Indirect } \\
\text { evidence }\end{array}$ & $\begin{array}{l}\text { Impreci- } \\
\text { sion }\end{array}$ & $\begin{array}{l}\text { Other } \\
\text { consid- } \\
\text { erations }\end{array}$ & $\begin{array}{l}\text { Pem- } \\
\text { broli- } \\
\text { zumab }\end{array}$ & Chemo & $\begin{array}{l}\text { Relative } \\
(95 \% \\
\text { CI) }\end{array}$ & $\begin{array}{l}\text { Absolute } \\
(95 \% \\
\mathrm{Cl})\end{array}$ & & \\
\hline \multicolumn{13}{|c|}{ Death in up to 12 months } \\
\hline 1 & $\mathrm{RCT}$ & severe $^{a}$ & $\begin{array}{l}\text { not } \\
\text { severe }\end{array}$ & $\begin{array}{l}\text { not } \\
\text { severe }\end{array}$ & severe $^{b}$ & none & $\begin{array}{l}85 / 180 \\
(47.2 \%)\end{array}$ & $\begin{array}{l}99 / 179 \\
(55.3 \%)\end{array}$ & $\begin{array}{l}\text { RR } 0.87 \\
(0.70 \text { to } \\
1.05)\end{array}$ & $\begin{array}{l}7 \text { less per } \\
100 \\
\text { (from } 17 \\
\text { less to } 3 \\
\text { more) }\end{array}$ & $\begin{array}{l}\oplus \oplus \bigcirc \bigcirc \\
\text { LOW }\end{array}$ & $\begin{array}{l}\text { IM- } \\
\text { PORT- } \\
\text { ANT }\end{array}$ \\
\hline
\end{tabular}

RCT: Randomized clinical trial; Cl: Confidence interval; RR: Risk ratio

\section{Explanations}

a. A loss greater than $20 \%$

b. The result was not significant. Small sample size

\section{Pembrolizumab versus Placebo}

\begin{tabular}{|c|c|c|c|c|c|c|c|c|c|c|c|c|}
\hline \multicolumn{7}{|c|}{ Evaluation of certainty } & \multicolumn{2}{|c|}{$\mathrm{N}^{\circ}$ of patients } & \multicolumn{2}{|l|}{ Effect } & \multirow{2}{*}{$\begin{array}{l}\text { Certain- } \\
\text { ty }\end{array}$} & \multirow{2}{*}{$\begin{array}{l}\text { Impor- } \\
\text { tance }\end{array}$} \\
\hline $\begin{array}{l}\mathrm{N}^{0} \text { of } \\
\text { studies }\end{array}$ & $\begin{array}{l}\text { Design } \\
\text { of the } \\
\text { study }\end{array}$ & $\begin{array}{l}\text { Risk of } \\
\text { bias }\end{array}$ & $\begin{array}{l}\text { Incon- } \\
\text { sistency }\end{array}$ & $\begin{array}{l}\text { Indirect } \\
\text { evidence }\end{array}$ & $\begin{array}{l}\text { Impre- } \\
\text { cise }\end{array}$ & $\begin{array}{l}\text { Other } \\
\text { consid- } \\
\text { erations }\end{array}$ & $\begin{array}{l}\text { Pem- } \\
\text { broli- } \\
\text { zumab }\end{array}$ & Placebo & $\begin{array}{l}\text { Relative } \\
(95 \% \\
\mathrm{Cl})\end{array}$ & $\begin{array}{l}\text { Abso- } \\
\text { lute } \\
(95 \% \\
\mathrm{Cl})\end{array}$ & & \\
\hline \multicolumn{13}{|c|}{ Death in up to 12 months } \\
\hline 1 & RCT & severe $^{\mathbf{a}}$ & $\begin{array}{l}\text { not } \\
\text { severe }\end{array}$ & $\begin{array}{l}\text { not } \\
\text { severe }\end{array}$ & $\begin{array}{l}\text { not } \\
\text { severe }\end{array}$ & None & $\begin{array}{l}101 / 514 \\
(19.6 \%)\end{array}$ & $\begin{array}{l}142 / 505 \\
(28.1 \%)\end{array}$ & $\begin{array}{l}\text { RR } 0.70 \\
(0.56 \text { to } \\
0.87)\end{array}$ & $\begin{array}{l}\text { minus } 8 \\
\text { per } 100 \\
\text { (from } \\
\text { minus } 12 \\
\text { to minus } \\
4 \text { ) }\end{array}$ & $\begin{array}{l}\oplus \oplus \oplus \bigcirc \\
\text { MOD- } \\
\text { ERATE }\end{array}$ & $\begin{array}{l}\text { IM- } \\
\text { PORT- } \\
\text { ANT }\end{array}$ \\
\hline
\end{tabular}

RCT: Randomized clinical trial; Cl: Confidence interval; RR: Risk ratio

Explanations

a. A loss greater than $20 \%$ 


\section{SYNTHESIS OF EVIDENCE}

In patients with unresectable melanoma; stage III or IV; without prior therapy with ipilimumab; with no ocular melanoma or cerebral metastasis; wild-type or mutant Braf, pembrolizumab (first or second line) in comparison with ipilimumab: reduces the risk of death by $14 \%$ (NNT=7, 95\% CI, 4 to 16$)$, in up to 12 months. The quality of the evidence that supports this result is moderate.

In patients with progressive unresectable melanoma in stage III-IV, after ipilimumab or therapy with MEK or Braf inhibitor (or both), if positive for mutant $\mathrm{Bra}^{\mathrm{v}}{ }^{600}$, pembrolizumab in comparison with chemotherapy: showed no statistical difference in the risk of death in up to 12 months. The quality of the evidence that supports this result is low. However, pembrolizumab reduces the risk of adverse events in grade $\geq$ III - quality of evidence low.

In patients with cutaneous melanoma metastasis to a regional lymph node; stage IIIA, IIIB, or IIIC; with complete resection and regional lymphadenectomy; without distant metastasis and prior therapy, pembrolizumab in comparison with a placebo: Reduces the risk of death or recurrence by $8 \%(\mathrm{NNT}=12,95 \% \mathrm{CI}, 7$ to 30 ), in up to six months. The quality of the evidence that supports this result is moderate.

\section{DISCUSSION}

The evidence currently available on the efficacy and safety of pembrolizumab as the first or second line of treatment for advanced melanoma is based on three randomized clinical trials ${ }^{(3-5)}$.

The effectiveness results presented by the studies show that pembrolizumab decreased the risk of death in cases of unresectable melanoma in comparison with ipilimumab ${ }^{(3)}$, as well as in adjuvant therapy for stage III melanoma with lymph node involvement, with complete resection, compared with a placebo ${ }^{(5)}$; however, the magnitude of the benefit in the long term is not clear. For stage III-IV progressive unresectable melanoma, after ipilimumab or therapy with MEK or Beaf inhibitor (or both), if positive for mutant Braf ${ }^{600}$, pembrolizumab in comparison with chemotherapy showed no statistically significant reduction in the risk of death; however, this result should be considered with caution due to the high risk of bias, indicating a low quality of evidence ${ }^{(4)}$.

In this review, we chose to use, whenever possible, the branch of the study that used a dose of $2 \mathrm{mg} / \mathrm{kg}$ of pembrolizumab, Q3W, if there was a branch that used $10 \mathrm{mg}$ under the same conditions ${ }^{(4)}$.

Considering the three studies, the rates of patients with positive PD-L1 tumor ranged from $83.3 \%$ to $54 \%$ and negative PD-L1 from $26.7 \%$ to $11.5 \%$.

We did not consider the results of PD-L1 subgroup analyses of the studies in this review, due to the risk of false-positive results, avoiding the following question: is there indeed a significant difference in the treatment effect or it is merely a random occurrence (considering the absence of prior sample size definition and subsequent statistical power for this difference)?

\section{ANNEX I \\ Clinical question}

What is the impact of pembrolizumab on the outcomes of overall mortality (death from any cause) and adverse events in the treatment of patients with advanced melanoma when compared to chemotherapy alone?

\section{Structured question}

\begin{tabular}{l|l}
\hline $\mathbf{P}$ & $\begin{array}{l}\text { Adult patients with advanced melanoma (completely } \\
\text { resected or unresectable) without distant metastasis }\end{array}$ \\
\hline $\mathbf{I}$ & $\begin{array}{l}\text { Treatment with pembrolizumab compared with another or } \\
\text { no therapy }\end{array}$ \\
\hline $\mathbf{C}$ & - \\
\hline $\mathbf{O}$ & Death (any cause); death or recurrence; and adverse events \\
\hline
\end{tabular}

\section{Eligibility criteria}

The selection of the studies and the evaluation of the titles and abstracts obtained from the search strategy in the databases consulted were independently and blindly conducted in total accordance with the inclusion and exclusion criteria. Finally, studies with potential relevance were separated.

When the title and the summary were not enlightening, we sought for the full article.

Only studies with texts available in its entirety were considered for critical evaluation.

No restriction was made regarding the year of publication or language.

The following outcomes were excluded: quality of life, objective response, progression-free survival; subgroup analysis will not be evaluated (PD-L1 in tumor tissue) and cycles every two weeks.

Randomized clinical trial studies were included. 


\section{Search for papers}

Database

The search for evidence will be conducted on Medline virtual scientific information database, and, when necessary, manually in the references found from references.

The search in these databases was performed by the month of June 2019, and a systematic review was performed according to the Prisma recommendations.

\section{Search strategy}

PubMed: Melanomas OR Malignant melanoma OR Malignant Melanomas) AND Pembrolizumab AND Random*;

CENTRAL / Cochrane: (Melanomas OR melanoma) AND Pembrolizumab

\section{Critical evaluation}

Relevance - clinical importance

This guideline was prepared by means of a clinically relevant question in order to gather information in medicine to standardize approaches and assist in decision-making.

\section{Results application - External validity}

We will extract the following data from the studies: name of the author and year of publication, study population, intervention and comparison methods, absolute number of deaths and adverse events, time of follow-up.

Randomized clinical trials will have their risk of biases analyzed according to the following criteria: randomization, blinded allocation, double-blinding, losses, prognostic characteristics, presence of relevant outcome, time for the outcome, method for outcome measurement, sample size calculation, early interruption, presence of other biases.

The results will be presented as the difference in the risk of death or adverse events between pembrolizumab therapy and another or no treatment. The confidence level adopted was $95 \%$.

The results of the studies included will be meta-analyzed by RevMan $5.3^{(1)}$, and the difference in overall risk will be the final measure used to support the synthesis of evidence that will answer the clinical question of this review.

The quality of evidence will be graded as high, moderate, low, or very low using the Grade instrument ${ }^{2}$ and taking into account the risk of bias, the presence of inconsistency, vagueness or indirect evidence in the meta-analysis of the outcomes of death and adverse events, and the presence of publication bias.

\section{Results}

The search for evidence retrieved 323 papers, of which six were selected based on their title and abstract on immunotherapy with pembrolizumab, for the treatment of patients with advanced melanoma, in comparison with ipilimumab, chemotherapy, or a placebo. The six studies that met the eligibility criteria were then were accessed for analysis of their full text. Of the six studies, three were selected to support this assessment ${ }^{3-5}$; the grounds for exclusion and the list of studies excluded are available in the references, Figure 1, and Table 5.

The selection of retrieved from the virtual databases of scientific information is detailed in the flowchart below:

\section{FIGURE 1. FLOWCHART}

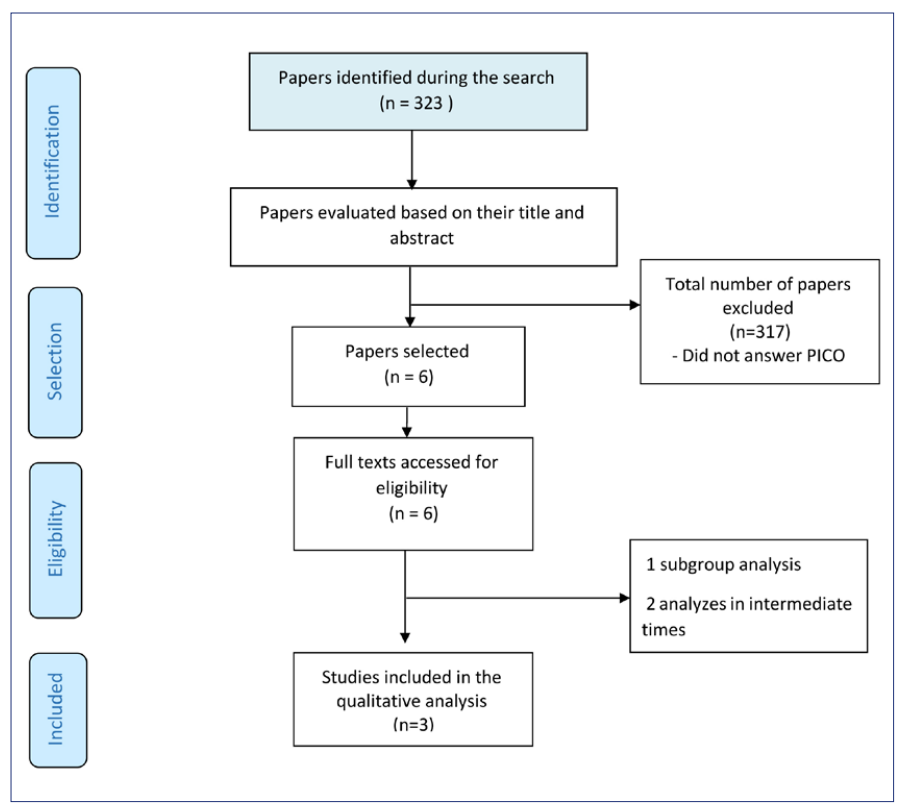

TABLE 5. STUDIES EXCLUDED AND REASON FOR EXCLUSION

\begin{tabular}{|l|l|}
\hline Study & Reason for exclusion \\
\hline Carlino MS, 2018 & Subgroup analysis \\
\hline Ribas A, 2015 & Analysis in an intermediate time \\
\hline Robert C, 2015 & Analysis in an intermediate time \\
\hline
\end{tabular}

\section{Conflict of interest}

There is no conflict of interest related to this review that can be declared by any of the authors. 


\section{Final declaration}

The Guidelines Project, an initiative of the Brazilian Medical Association in partnership with the Specialty Societies, aims to reconcile medical information in order to standardize approaches that can aid the physician's reasoning and decision-making

\section{REFERENCES}

1. Review Manager (RevMan) [Computer program]. Version 5.3. Copenhagen: The Nordic Cochrane Centre, The Cochrane Collaboration, 2014.

2. GRADEpro GDT: GRADEpro Guideline Development Tool [Software] McMaster University, 2015 (developed by Evidence Prime, Inc.). Available from gradepro.org.

3. Schachter |, Ribas A, Long GV, Arance A, Grob IJ, Mortier L, et al. Pembrolizumab versus ipilimumab for advanced melanoma: final overall survival results of a multicentre, randomised, open-label phase 3 study (KEYNOTE-006). Lancet 2017 21;390:1853-1862. PMID: 28822576

4. Hamid O Puzanov |, Dummer R, Schachter |, Daud A, Schadendorf D, et al. Final analysis of a randomised trial comparing pembrolizumab versus investigator-choice chemotherapy for ipilimumab-refractory advanced melanoma. Eur | Cancer 2017;86:37-45. PMID: 28961465

5. Eggermont $A M M$, Blank CU, Mandala M, Long GV, Atkinson V, Dalle S, et al. Adjuvant Pembrolizumab versus Placebo in Resected Stage III Melanoma. N Engl | Med 2018 10;378:1789-1801. PMID: 29658430 process. The information contained in this project must be submitted to the evaluation and criticism of the physician responsible for the conduct to be followed, given the reality and clinical condition of each patient.

\section{PAPERS EXCLUDED}

(REASONS IN TABLE 9 - ANNEXES)

Carlino MS, Long GV, Schadendorf D, Robert C, Ribas A, Richtig E, et al. Outcomes by the line of therapy and programmed death-ligand 1 expression in patients with advanced melanoma treated with pembrolizumab or ipilimumab in KEYNOTE-006: A randomised clinical trial. Eur | Cancer 2018;101:236-243. PMID: 30096704

Ribas A, Puzanov I, Dummer R, Schadendorf D, Hamid O, Robert C, et al. Pembrolizumab versus investigator-choice chemotherapy for ipilimumab-refractory melanoma (KEYNOTE-002): a randomised, controlled, phase 2 trial. Lancet Oncol 2015;16:908-18. PMID: 26115796

Robert C, Schachter J, Long GV, Arance A, Grob J), Mortier L, et al. Pembrolizumab versus I pilimumab in Advanced Melanoma. N Engl | Med 2015 25:372:2521-32. PMID: 25891173 